\title{
Pembuatan Aplikasi Augmented Reality Siklus Hidrologi sebagai Media Pembelajaran Berbasis Android
}

\author{
Hardiyanto $^{1)}$ R. Rizal Isnanto ${ }^{2)}$, Ike Pertiwi Windasari ${ }^{2)}$ \\ Program Studi Sistem Komputer Fakultas Teknik Universitas Diponegoro \\ Jalan Prof. Sudharto, Tembalang, Semarang, Indonesia \\ kotaksurat.hardi@gmail.com
}

\begin{abstract}
Abstrak-Daur air atau bisa disebut dengan siklus hidrologi merupakan materi pelajaran Ilmu Pengetahuan Alam tingkat Sekolah Dasar kelas V. Materi ini membahas tentang proses perputaran air yang ada di muka bumi. Media pembelajaran yang saat ini digunakan masih didominasi oleh buku yang berisi tulisan dan gambar saja. Penggunaan gambar yang telah tersedia dalam buku teks membuat siswa cenderung pasif dan kurang interaktif karena media gambar tidak mampu memberikan respon timbal balik, kurang terlihat nyata dan kurang menarik bagi siswa. Penelitian ini bertujuan untuk menghasilkan sebuah perangkat lunak berbasis android yang dapat menampilkan pemodelan siklus air atau hidrologi dalam bentuk tiga dimensi memanfaatkan teknologi augmented reality.

Penelitian ini menggunakan metode pengembangan multimedia meliputi tahap konsep, tahap desain, tahap pengumpulan materi, tahap pembuatan, tahap pengujian dan tahap distribusi. Aplikasi ini dibuat menggunakan Unity 3D, serta Vuforia sebagai Software Development Kit (SDK). Aplikasi berjalan pada perangkat bergerak dengan sistem operasi Android. Pada tahap pengujian dilakukan pengujian dengan metode Black Box yang meliputi pengujian fungsi aplikasi, pengujian intensitas cahaya, sudut dan jarak antara kamera dengan penanda.

Berdasarkan hasil pengujian terhadap aplikasi yang telah dibangun, seluruh fungsi menu dan antarmuka dapat berfungsi dengan baik. Deteksi penanda oleh kamera mendapatkan hasil yang berbeda-beda. Proses deteksi penanda pada sudut $90^{\circ}$ tidak baik karena proses pembacaan penanda tidak dapat ditangkap oleh sistem. Selain itu, jarak yang baik untuk sistem mengidentifikasi penanda yaitu lebih dari $10 \mathrm{~cm}$.
\end{abstract}

Kata kunci-Augmented Reality, Siklus Hidrologi, Android, Black box

\section{Pendahuluan}

$\mathrm{P}$ ERKEMBANGAN teknologi hiburan yang semakin menyuguhkan hal-hal menarik dan interaktif seperti film kartun maupun animasi tiga dimensi (3D) justru membuat minat belajar siswa semakin berkurang. Sedangkan media pembelajaran yang saat ini digunakan masih didominasi oleh buku yang berisi tulisan dan gambar saja. Penggunaan gambar dua dimensi (2D) sebagai penunjang pembelajaran agar siswa tidak merasa bosan dan lebih berimajinatif sekarang ini kurang membantu mengatasi masalah diatas. Penggunaan gambar diam yang telah tersedia dalam buku teks membuat siswa cenderung pasif dan kurang interaktif karena media gambar tidak mampu memberikan respon timbal balik, kurang terlihat nyata dan kurang menarik bagi siswa ${ }^{[12]}$.

Augmented Reality (AR) merupakan salah satu inovasi teknologi dalam meningkatkan interaksi antara manusia dan $\operatorname{mesin}^{[3]}$. Teknologi AR banyak dikembangkan dalam pembuatan media pembelajaran yang inovatif sebagai alat bantu guru dalam proses pembelajaran di kelas, dan tidak dapat menggantikan guru secara keseluruhan. AR memiliki beberapa karakakteristik, yaitu penggabungan benda-benda nyata dan maya di lingkungan nyata, berjalan secara interaktif dalam waktu nyata, dan terdapat integrasi antar benda dalam tiga dimensi, yaitu benda maya terintegrasi dalam dunia nyata ${ }^{[7]}$.

Atas dasar itulah diharapkan dengan dibuatnya AR siklus hirologi berbasis android ini dapat menciptakan alat maupun menambah variasi media pembelajaran baru dalam memahami siklus air yang lebih interaktif dan menarik serta dapat membantu menyampaikan informasi tentang siklus air kepada siswa.

Penelitian ini bertujuan untuk menghasilkan sebuah perangkat lunak berbasis android yang dapat menampilkan pemodelan siklus air atau hidrologi dalam bentuk tiga dimensi memanfaatkan teknologi augmented reality, serta menambah variasi media pembelajaran yang menarik untuk siswa di sekolah maupun di luar sekolah.

Dalam penulisan Tugas Akhir ini, penulis membatasi permasalahan dalam lingkup sebagai berikut.

Aplikasi augmented reality ini bekerja pada sistem operasi Android.

1. Materi siklus hidrologi yang digunakan mengikuti materi untuk kelas 5 SD yaitu meliputi penguapan air (evaporasi), pengembunan (kondensasi), jatuhnya air (presipitasi), dan penyerapan air (infiltrasi).

2. Aplikasi ini dibuat menggunakan Vuforia SDK

3. Pengujian aplikasi menggunakan metode kotak hitam (black box testing) dilakukan pada ponsel Lenovo A526 dengan sistem operasi Android versi 4.3 Jelly Bean.

4. Penelitian ini tidak berfokus pada pembuatan objek dan animasi 3D siklus hidrologi dan tidak membahas dampak dari penggunaan aplikasi tersebut di masyarakat.

\section{LANDASAN TEORI}

\section{A. Augmented Reality}

Augmented Reality (AR) adalah sebuah variasi dari Virtual Environment atau Virtual Reality (VR) seperti yang umum diketahui.Teknologi Virtual Environment secara lengkap membenamkan seorang pengguna teknologi tersebut ke dalam lingkungan sintesis. Disaat pembenaman, pengguna teknologi tersebut tidak dapat melihat dunia nyata di sekitarnya.Dalam perbedaan yang kontras, AR memberi celah kepada pengguna teknologi tersebut untuk melihat dunia nyata dengan objek virtual yang ditambahkan di atas dunia nyata. Oleh karena itu, AR menambahkan sesuatu pada dunia nyata daripada menggantikan dunia nyata ${ }^{[7]}$. 


\section{B. Siklus Hidrologi}

Siklus hidrologi adalah gerakan air laut ke udara, yang kemudian jatuh ke permukaan tanah lagi sebagai hujan atau bentuk presipitasi lain, dan akhirnya mengalir ke laut kembali $^{[8]}$. Air di bumi secara terus menerus mengalami sirkulasi berupa proses penguapan, presipitasi dan pengaliran keluar (outflow). Air menguap ke udara dari permukaan tanah dan laut, berubah menjadi awan sesudah melalui beberapa proses dan kemudian jatuh sebagai hujan atau salju ke permukaan laut atau daratan. Sebelum jatuh ke permukaan bumi sebagian langsung menguap ke udara dan sebagian jatuh ke permukaan bumi.Tidak semua hujan yang jatuh ke permukaan bumi mencapai permukaan tanah. Sebagian akan tertahan oleh tumbuh-tumbuhan di mana sebagian akan menguap dan sebagian lagi akan jatuh atau mengalir melalui daun-daun ke permukaan $\operatorname{tanah}^{[9]}$

Sebagian air hujan yang jatuh ke permukaan tanah akan masuk ke dalam tanah (infiltrasi). Sebagian lagi yang merupakan kelebihan akan mengisi lekuk-lekuk permukaan tanah, kemudian mengalir ke daerah-daerah yang rendah, masuk ke sungai-sungai dan akhirnya ke laut ${ }^{[9]}$.

\section{Multimedia}

Definisi multimedia secara umum adalah penggabungan berbagai informasi menggunakan fasilitas dari komputer. Multimedia yang berasal dari kata multi yang berarti banyak atau lebih dari satu dan media yang dapat diartikan penyajian suatu tempat. Multimedia adalah pemanfaatan komputer untuk membuat dan mengabungkan teks, suara, gambar, video dan animasi dengan menggunakan link dan alat yang memungkinkan pemakaian melakukan navigasi, berinteraksi, dan berkomunikasi ${ }^{[10]}$.

\section{Media Pembelajaran}

Menurut Briggs (1977), media pembelajaran adalah sarana fisik untuk menyampaikan isi/materi pembelajaran seperti buku, film, video, dan sebagainya. Kemudian menurut National Association Education (1969), menyatakan bahwa media pembelajaran adalah sarana komunikasi dalam bentuk cetak maupun pandang dengar, termasuk teknologi perangkat keras. Jadi dari beberapa definisi yang telah disebutkan, dapat disimpulkan bahwa media pembelajaran adalah alat bantu proses belajar mengajar. Segala sesuatu yang dapat dipergunakan dalam merangsang pikiran, perasaan, perhatian dan kemampuan pembelajar dari pengajar kepada pembelajar sehingga dapat mendorong terjadinya proses belajar ${ }^{[5]}$.

\section{E. Android}

Android adalah sebuah sistem operasi untuk perangkat mobile berbasis linux yang mencakup sistem operasi, middleware, dan aplikasi.Android menyediakan platform terbuka bagi para pengembang untuk menciptakan aplikasi mereka. Awalnya, Google Inc. membeli Android Inc. yang merupakan pendatang baru yang membuat peranti lunak untuk ponsel/smartphone $e^{[6]}$.

\section{F. Unity}

Unity adalah sebuah game engine yang berbasis lintas platform. Unity dapat digunakan untuk membuat sebuah game yang bisa digunakan pada perangkat komputer, ponsel pintar Android, iPhone, PS3, dan bahkan X-BOX. Unity adalah sebuah sebuah tool yang terintegrasi untuk membuat game, arsitektur bangunan dan simulasi. Unity bisa untuk games PC dan games online. Untuk games online diperlukan sebuah plugin, yaitu Unity Web Player, sama halnya dengan Flash Player pada Browser. Unity tidak dirancang untuk proses perancangan atau pemodelan, dikarenakan Unity bukan alat untuk mendesain ${ }^{[4]}$.

\section{G. Blender}

Blender adalah perangkat lunak untuk grafis 3 dimensi yang gratis dan populer di kalangan desainer. Blender dapat digunakan untuk membuat animasi 3 dimensi. Perangkat lunak ini juga memiliki kemampuan untuk membuat permainan. Blender tersedia untuk berbagai sistem operasi Microsoft Windows, Mac OS X, Linux, IRIX, Solaris, NetBSD, FreeBSD, dan OpenBSD ${ }^{[1]}$.

\section{H. Vuforia}

Vuforia merupakan salah satu library untuk Augmented Reality, yang menggunakan sumber yang konsisten mengenai computer vision yang fokus pada image recognitio. Dengan support untuk iOS, Android, dan Unity3D, platform Vuforia mendukung para pengembang untuk membuat aplikasi yang dapat digunakan di hampir seluruh jenis smartphone dan tablet.

\section{Metodologi Pengembangan Multimedia}

Metodologi yang digunakan adalah Multimedia Development Life Cycle (MDLC) yang bersumber dari Luther dan sudah dimodifikasi oleh Sutopo. Metodologi pengembangan multimedia Luther yang sudah dimodifikasi oleh Sutopo ditunjukkan pada Gambar 1.

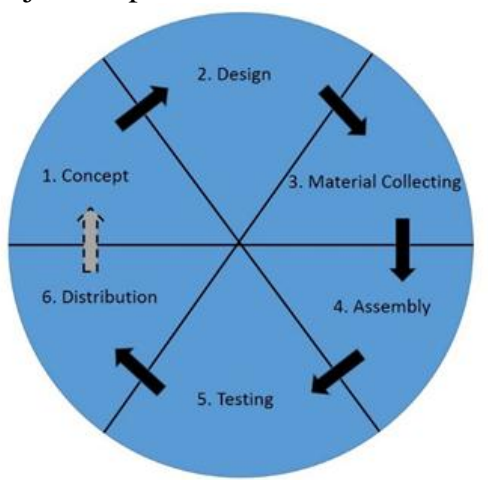

Gambar 1. Tahapan pengembangan multimedia ${ }^{[11]}$

Metodologi pengembangan multimedia tersebut terdiri dari enam tahap, yaitu konsep, desain, pengumpulan materi, pembuatan pengujian dan distribusi. Keenam tahap ini tidak harus berurutan dalam prakteknya, tahap-tahap tersebut dapat saling bertukar posisi. Meskipun begitu, tahap konsep memang harus menjadi hal yang pertama kali dikerjakan ${ }^{[2]}$.

\section{PERANCANGAN SISTEM}

Pengembangan aplikasi ini menggunakan Metodologi Pengembangan Multimedia yang terdiri atas tahap konsep, desain, pengumpulan materi, pembuatan, pengujian, dan distribusi. Keenam tahap ini tidak harus berurutan dalam prakteknya, tahap-tahap tersebut dapat saling bertukar posisi. Meskipun begitu, tahap konsep memang harus menjadi hal yang pertama kali dikerjakan ${ }^{[2]}$.

\section{A. Konsep}

Aplikasi ini dibuat bertujuan sebagai media pembelajaran yang berisi tentang materi siklus hidrologi atau air.Aplikasi ini bersifat multimedia sehingga menggunakan perpaduan antara teks, suara, dan gambar dalam merancang desain aplikasi.

Pada tahap ini penulis membuat beberapa kriteria yang menjadi konsep dari aplikasi yang akan dibuat. Adapun 
beberapa kriteria yang diharapkan ada pada aplikasi ini antara lain:

1. Dapat dijalankan pada perangkat bergerak (mobile device) berbasis Android.

2. Aplikasi memiliki antarmuka yang banyak warna.

3. Pengguna dapat melihat pemodelan 3D siklus hidrologi beserta narasi tentang proses tersebut.

\section{B. Desain atau Perancangan}

Dalam tahap perancangan ini dibagi menjadi tiga yaitu merancang desain tampilan antarmuka aplikasi, merancang penanda atau marker dan merancang pembuatan alur berjalannya aplikasi melalui diagram alir atau flowchart.

Terdapat beberapa perancangan antarmuka pada aplikasi ini. Diantaranya yaitu tampilan halaman utama aplikasi yang ditunjukkan oleh Gambar 2, tampilan halaman Mulai yang ditunjukkan oleh Gambar 3, tampilan halaman Panduan yang ditunjukkan oleh Gambar 4, tampilan halaman Tentang Aplikasi yang ditunjukkan oleh Gambar 5.

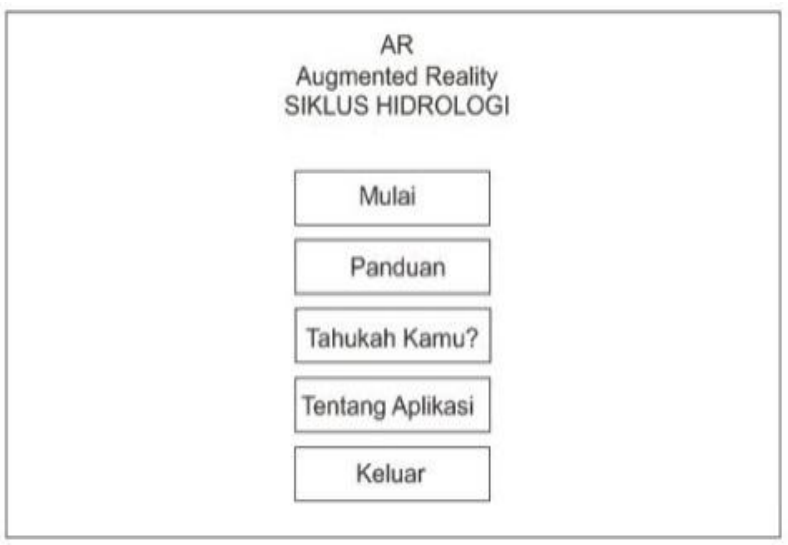

Gambar 2. Perancangan antarmuka halaman utama aplikasi.

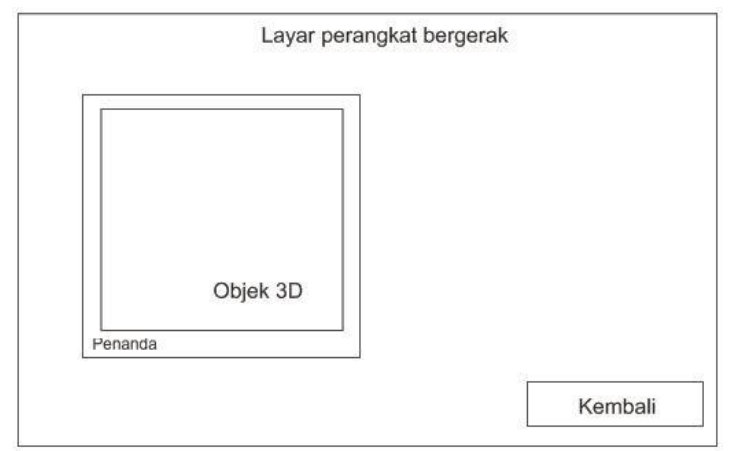

Gambar 3. Perancangan antarmuka halaman Mulai

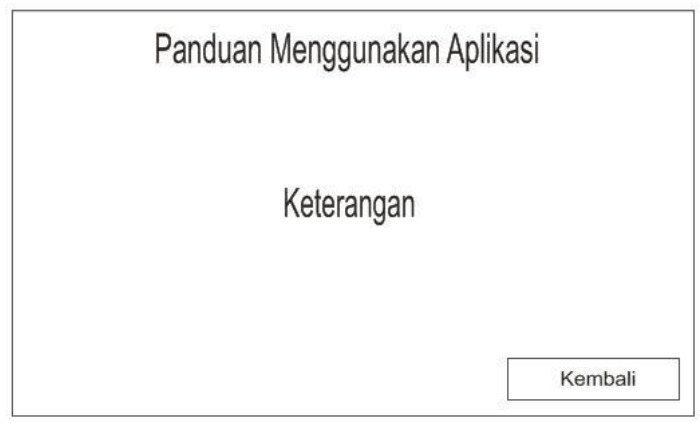

Gambar 4. Perancangan antarmuka halaman Panduan

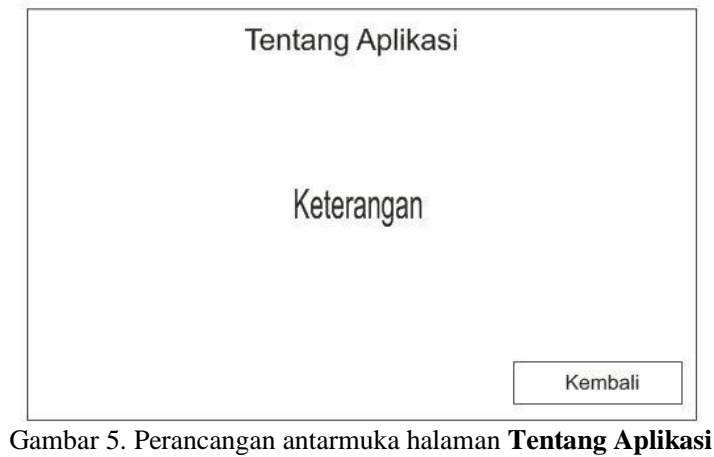

Penanda-penanda dirancang agar mempunyai tema tentang siklus hidrologi. Desain lima objek 3D berserta lima penanda tersebut ditunjukkan pada Gambar 6 sampai dengan Gambar 10.

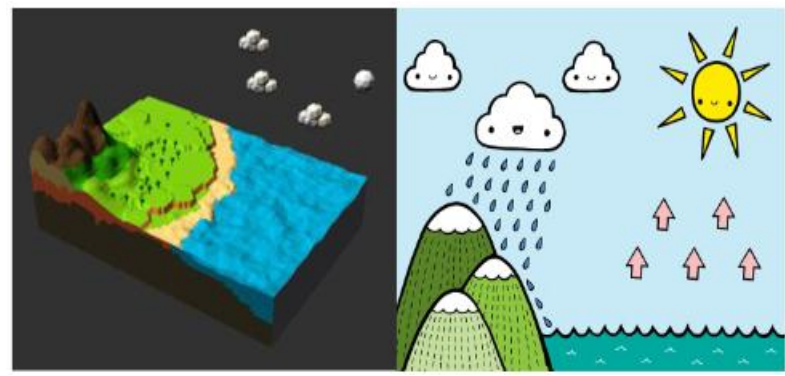

Gambar 6. Objek 3D siklus hidrologi \& penanda

Desain objek evaporasi dan penanda ditunjukkan pada Gambar 7.

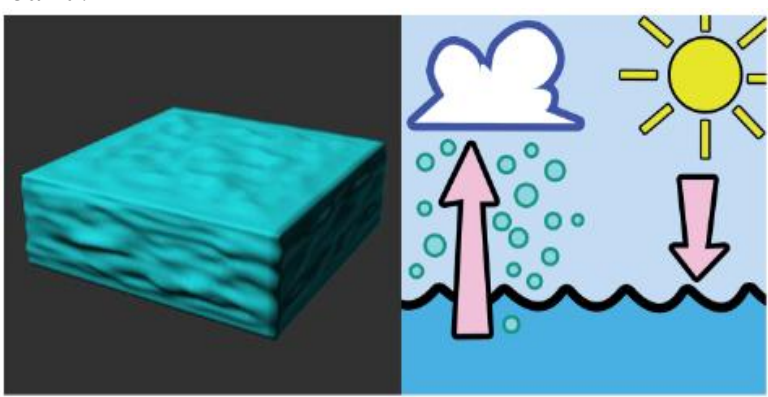

Gambar 7. Objek 3D evaporasi \& penanda

Desain objek kondensasi dan penanda ditunjukkan pada Gambar 8.

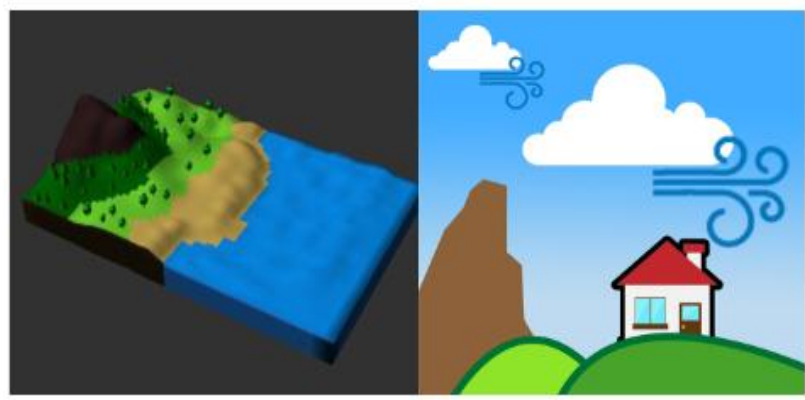

Gambar 8. Objek 3D evaporasi \& penanda

Desain objek hujan dan penanda ditunjukkan pada Gambar 9

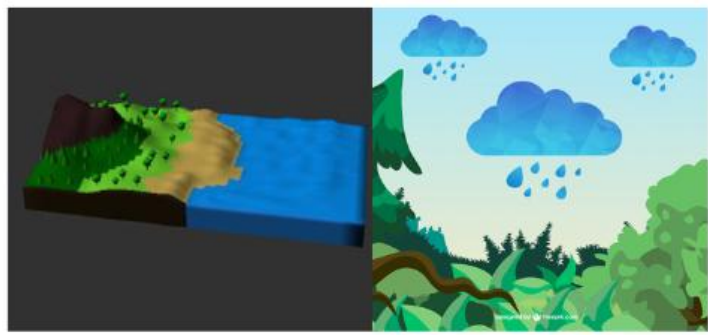

Gambar 9. Objek 3D hujan \& penanda 
Terakhir merupakan desain objek hujan dan penanda ditunjukkan pada Gambar 10.

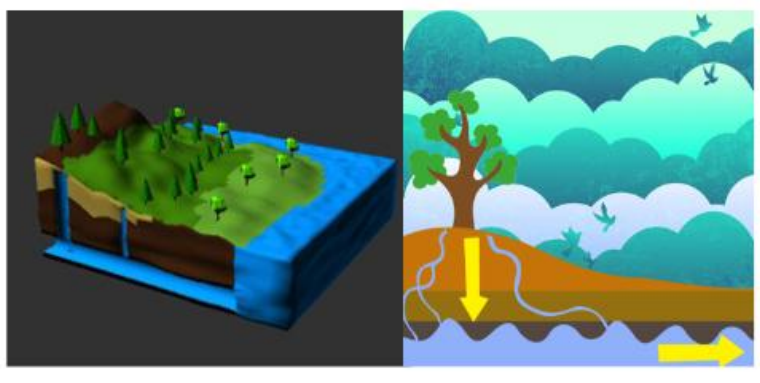

Gambar 10. Objek 3D infiltrasi \& penanda

Saat pengguna membuka aplikasi disajikan halaman utama aplikasi atau biasa disebut dengan home. Terdapat lima menu pilihan yaitu Mulai, Panduan, Tahukah Kamu?, Tentang Aplikasi, dan Keluar. Diagram alir pada menu awal atau halaman utama aplikasi ditunjukkan pada Gambar 11.

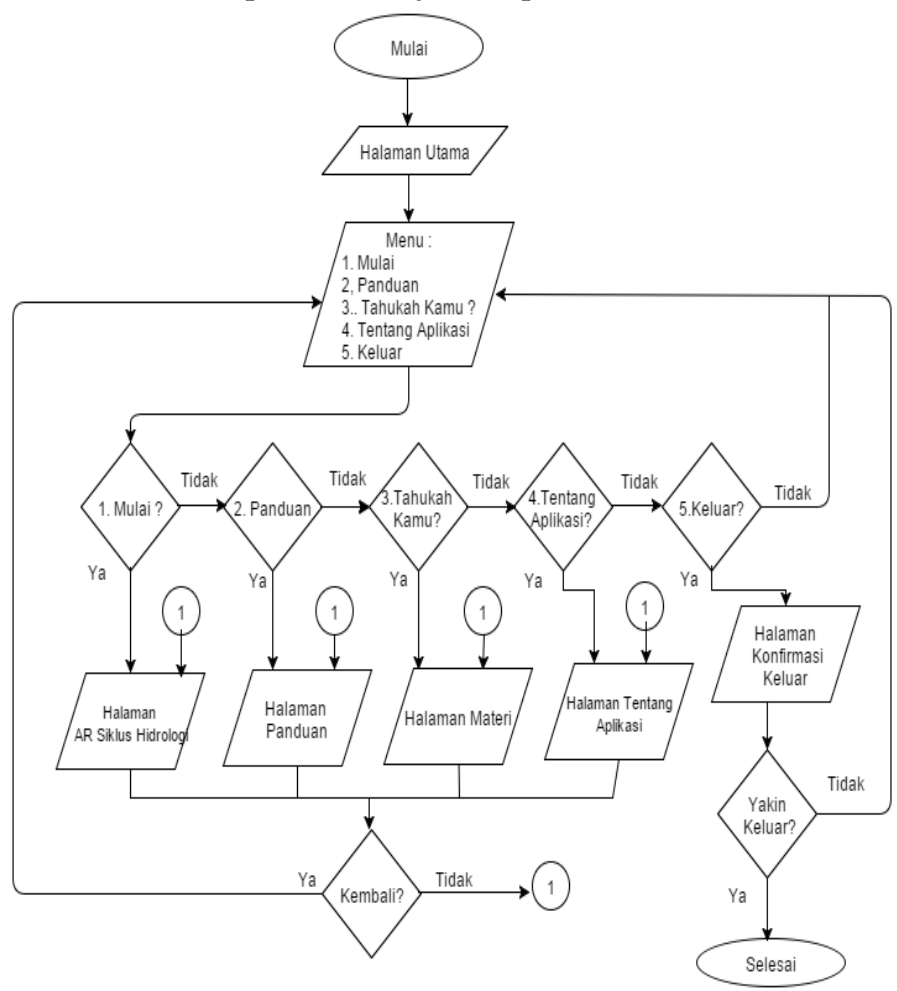

Gambar 11. Diagram alir halaman utama

Diagram alir halaman Mulai dapat dilihat pada Gambar 12.

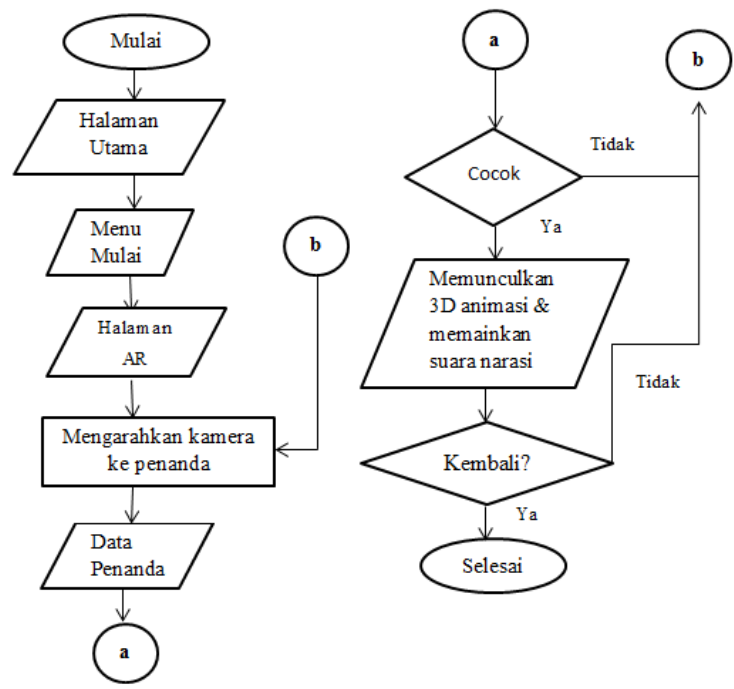

Gambar 12. Diagram alir halaman Mulai
Diagram alir pada halaman Panduan ditunjukkan pada Gambar 13

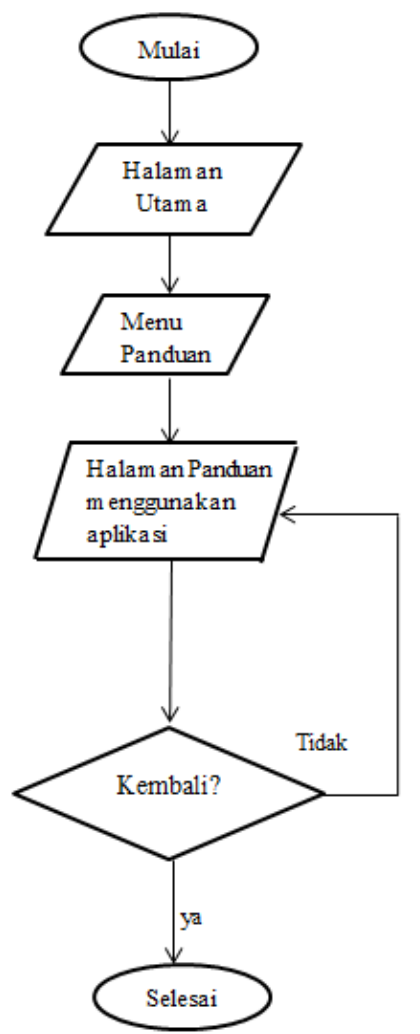

Gambar 13. Diagram alir halaman Panduan

Diagram alir pada halaman Tahukah Kamu? ditunjukkan pada Gambar 14 dan Gambar 15.

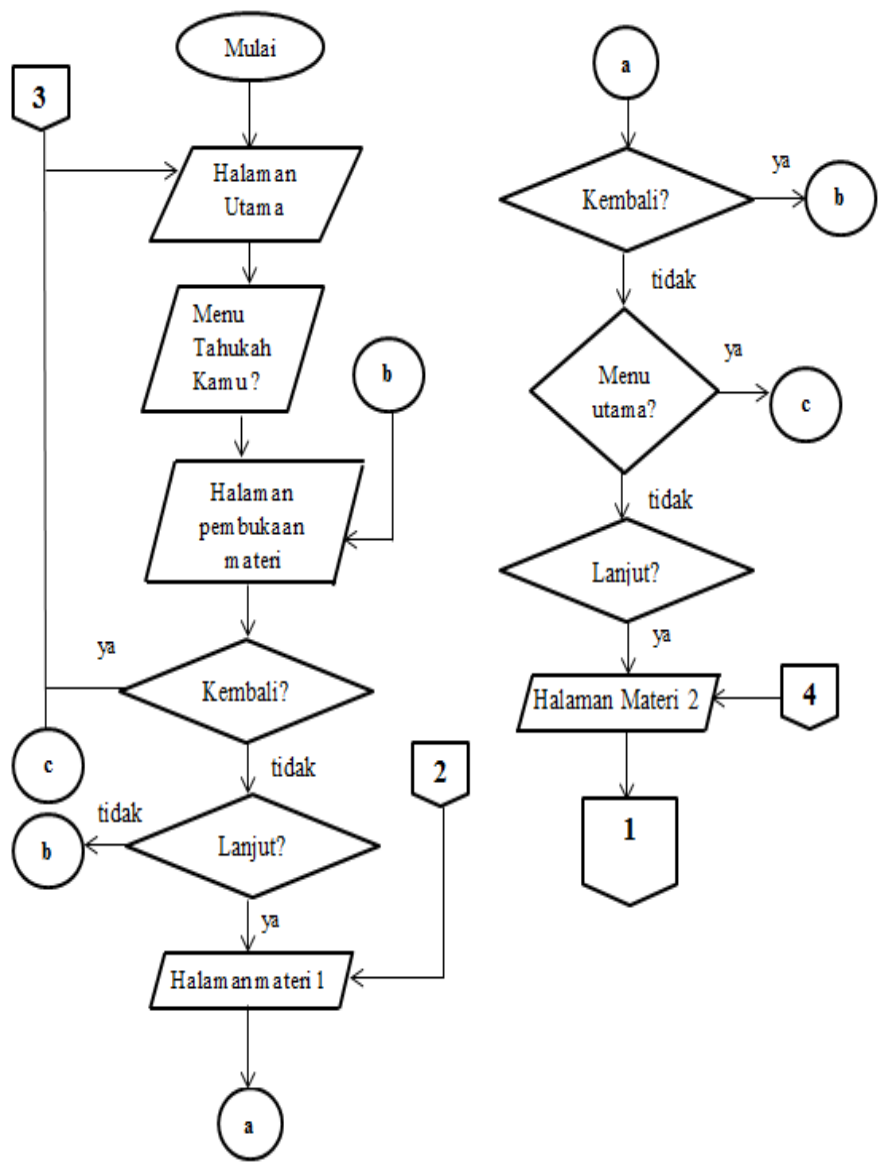

Gambar 14. Diagram alir halaman Tahukah Kamu? 


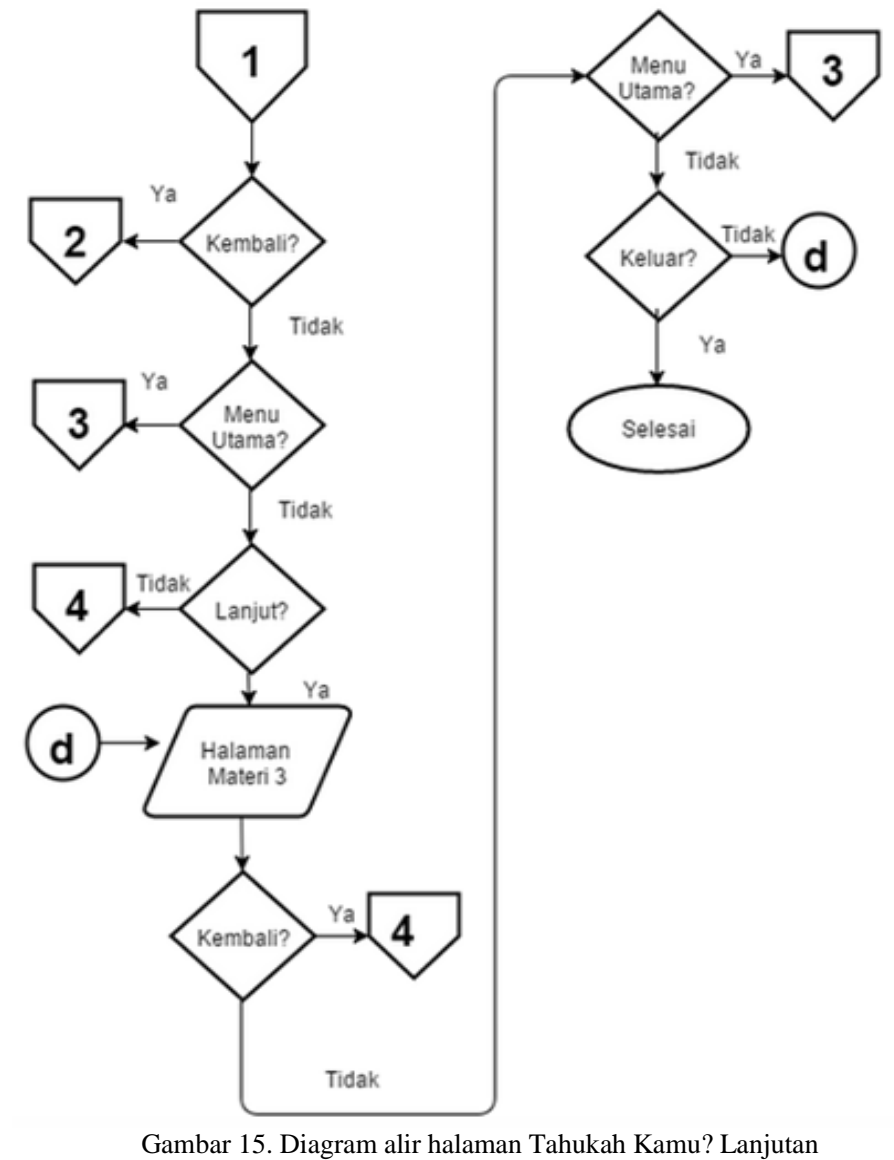

Diagram alir pada halaman Tentang Aplikasi ditunjukkan pada Gambar 16.

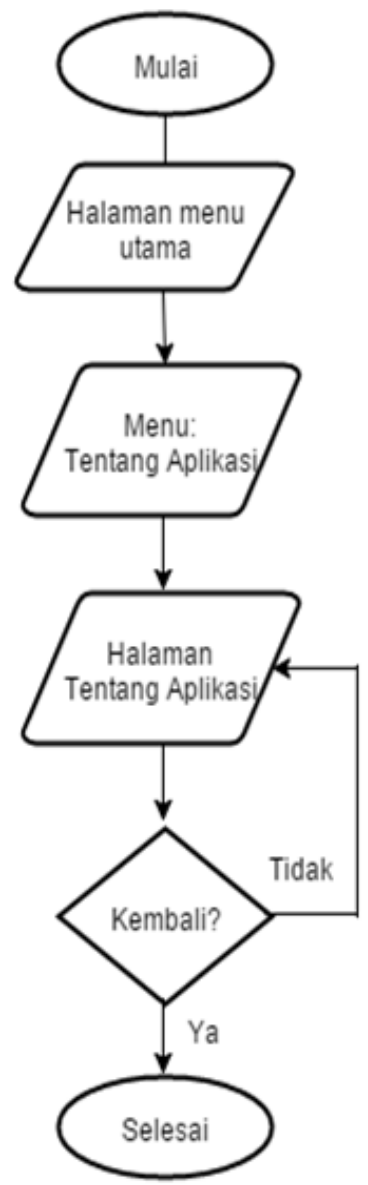

Gambar 16. Diagram alir halaman Tentang Aplikasi
Selanjutnya adalah pilihan menu Keluar. Menu ini berfungsi untuk keluar dari aplikasi. Menu ini akan menuju halaman konfirmasi keluar. Jika memilih tombol Ya maka akan keluar dari aplikasi, jika memilih tombol Tidak maka menuju halaman utama aplikasi. Diagram alir menu Keluar ditunjukkan pada Gambar 17.

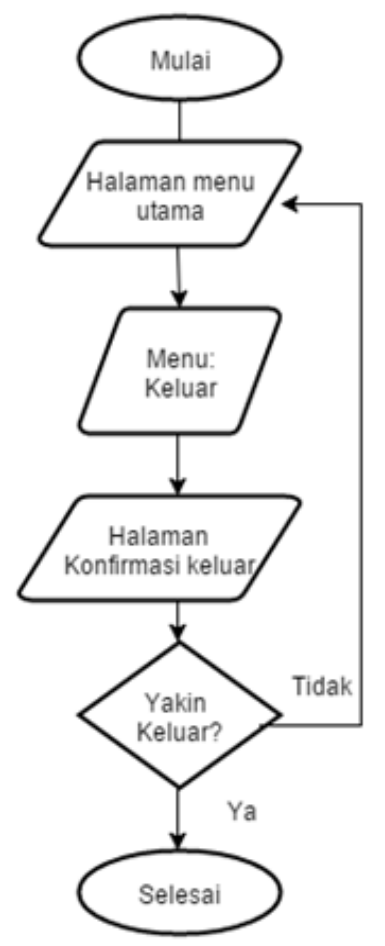

Gambar 17. Diagram alir halaman Keluar

\section{Pengumpulan Materi}

Dalam tahap ini dilakukan pengumpulan materi yang diperlukan dalam pembuatan aplikasi siklus hidrologi, diantaranya konten-konten tampilan grafis atau gambar, objek 3D, serta efek suara yang diunduh dari beberapa sumber. Khusus untuk objek 3D penulis mempelajari cara pembuatannya melalui video-video yang ada di website Youtube. Selain itu adapun konten materi berkaitan dengan siklus hirologi dari menu Tahukah Kamu?diambil dari buku sekolah elektronik Ilmu Pengetahuan Alam (IPA) SD kelas 5 terbitan Pusat Perbukuan Departemen Pendidikan Nasional (Depdiknas) tahun 2009 yang diunduh dari http://www.bse.mahoni.com/. Buku tersebut menjadi acuan materi saja pada aplikasi namun tidak disamakan persis.

\section{IV.PEMBUATAN DAN PENGUJIAN}

\section{A. Pembuatan Aplikasi}

Tahapan pembuatan aplikasi merupakan tahapan dimana konsep direalisasikan dengan menggunakan materi yang sudah dikumpulkan sehingga dihasilkan aplikasi yang dapat bekerja sesuai dengan fungsinya masing-masing.

1) Memasukan Pustaka Vuforia pada Unity: Tahapan ini merupakan tahapan awal implementasi sistem, yang mana pada pengembangan aplikasi buku dongeng beranimasi ini digunakan Unity sebagai software pengembangannya, dan Software Development Kit yang digunakan adalah Vuforia. Oleh karena itu, pustaka dari Vuforia diperlukan untuk di-Load pada Unity yang akan digunakan tersebut. Pustaka Vuforia Unity dapat diunduh di situs https://developer.vuforia.com/ yang merupakan situs resmi Vuforia Qualcomm. Gambar 18 menunjukkan package vuforia yang diimpor ke dalam Unity. 


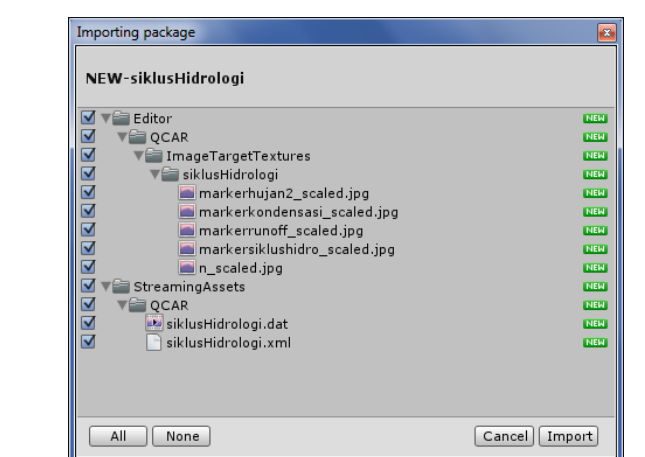

Gambar 18. Package Vuforia yang di import ke dalam Unity

2) Implementasi Halaman Aplikasi: Halaman aplikasi yang dibuat adalah halaman utama aplikasi, halaman Mulai, Panduan, Tahukah Kamu?,Tentang Aplikasi, dan Keluar. Halaman-halaman tersebut ditunjukkan berurutan pada Gambar 19 sampai dengan Gambar 22.

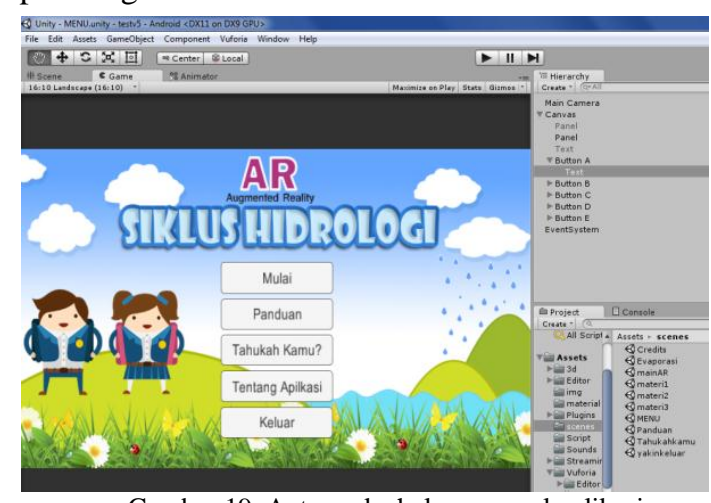

Gambar 19. Antarmuka halaman awal aplikasi.

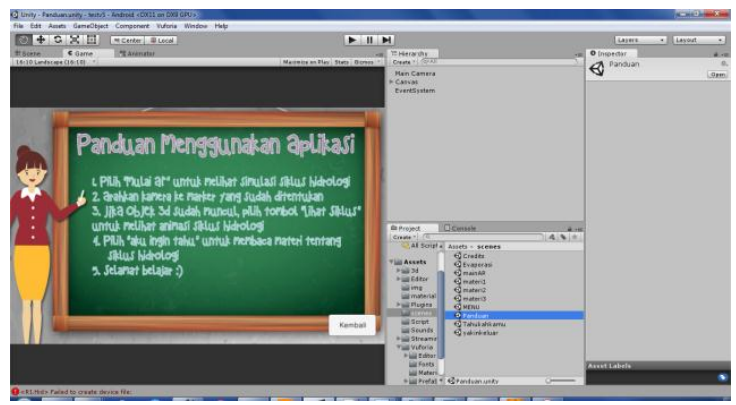

Gambar 20. Antarmuka halaman panduan

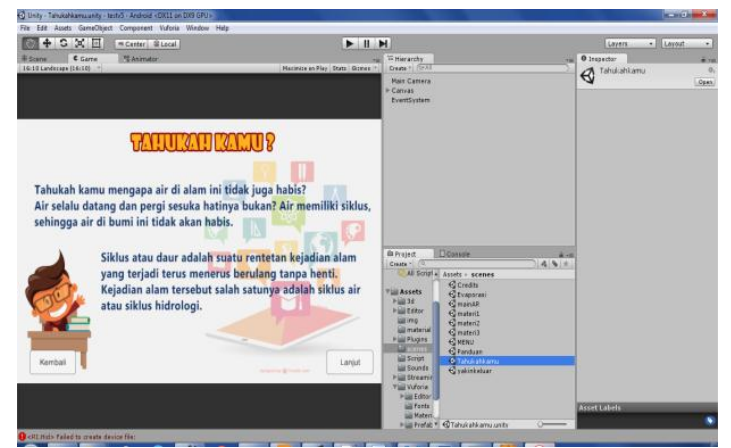

Gambar 21. Antarmuka halaman Tahukah Kamu?

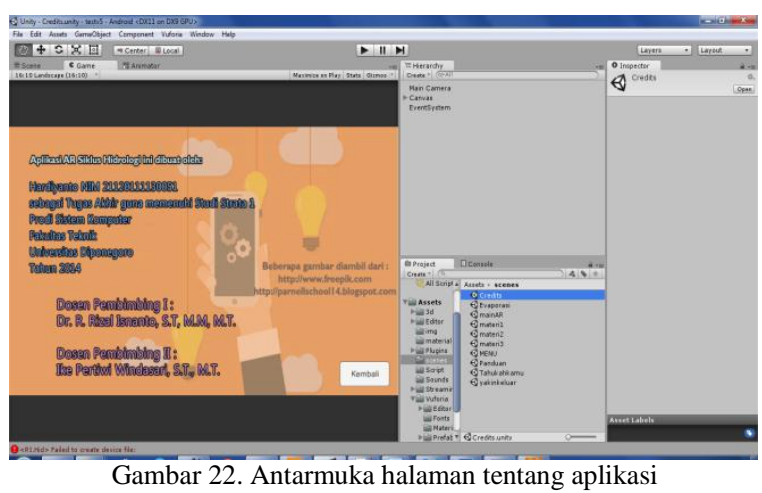

\section{B. Pengujian Aplikasi}

Pengujian aplikasi ini dilakukan dengan metode pengujian kotak hitam atau black box, dimana metode pengujian perangkat lunak black box ini bertujuan memastikan fungsifungsi daripada aplikasi yang telah dibangun dapat berjalan dengan baik dan untuk mengetahui apakah masih terjadi kesalahan program atau tidak.

1) Pengujian Penanda: Pengujian penanda atau marker dilakukan untuk mengetahui apakah setiap penanda yang digunakan mengalami kesalahan atau tidak. Pengujian dilakukan setelah mengakses menu Mulai. Hasil dari pengujian dapat dilihat pada Tabel 1.

TABELI

PENGUJIAN PENANDA

\begin{tabular}{|c|c|c|c|}
\hline $\begin{array}{c}\text { Data } \\
\text { Masukan }\end{array}$ & $\begin{array}{c}\text { Bentuk } \\
\text { Pengujian }\end{array}$ & $\begin{array}{l}\text { Hasil yang } \\
\text { Diharpkan }\end{array}$ & $\begin{array}{c}\text { Hasil } \\
\text { Pengujian }\end{array}$ \\
\hline $\begin{array}{l}\text { Penanda } \\
\text { Siklus } \\
\text { Hidrologi }\end{array}$ & $\begin{array}{l}\text { Mengarahkan } \\
\text { kamera } \\
\text { perangkat } \\
\text { bergerak ke } \\
\text { penanda }\end{array}$ & $\begin{array}{c}\text { Menampilkan } \\
\text { objek 3D } \\
\text { siklus } \\
\text { hidrologi dan } \\
\text { suara narasi } \\
\text { siklus } \\
\text { hidrologi } \\
\end{array}$ & Berhasil \\
\hline $\begin{array}{l}\text { Penanda } \\
\text { Evaporasi }\end{array}$ & $\begin{array}{l}\text { Mengarahkan } \\
\text { kamera } \\
\text { perangkat } \\
\text { bergerak ke } \\
\text { penanda } \\
\end{array}$ & $\begin{array}{c}\text { Menampilkan } \\
\text { objek 3D } \\
\text { evaporasi dan } \\
\text { suara narasi } \\
\text { evaporasi } \\
\end{array}$ & Berhasil \\
\hline $\begin{array}{l}\text { Penanda } \\
\text { Kondensasi }\end{array}$ & $\begin{array}{l}\text { Mengarahkan } \\
\text { kamera } \\
\text { perangkat } \\
\text { bergerak ke } \\
\text { penanda }\end{array}$ & $\begin{array}{c}\text { Menampilkan } \\
\text { objek 3D } \\
\text { kondensasi } \\
\text { dan suara } \\
\text { narasi } \\
\text { kondensasi } \\
\end{array}$ & Berhasil \\
\hline $\begin{array}{l}\text { Penanda } \\
\text { Hujan }\end{array}$ & $\begin{array}{c}\text { Mengarahkan } \\
\text { kamera } \\
\text { perangkat } \\
\text { bergerak ke } \\
\text { penanda } \\
\end{array}$ & $\begin{array}{c}\text { Menampilkan } \\
\text { objek 3D } \\
\text { hujan dan } \\
\text { suara narasi } \\
\text { hujan } \\
\end{array}$ & Berhasil \\
\hline $\begin{array}{l}\text { Penanda } \\
\text { Infiltrasi }\end{array}$ & $\begin{array}{c}\text { Mengarahkan } \\
\text { kamera } \\
\text { perangkat } \\
\text { bergerak ke } \\
\text { penanda }\end{array}$ & $\begin{array}{c}\text { Menampilkan } \\
\text { objek 3D } \\
\text { hujan dan } \\
\text { suara narasi } \\
\text { hujan }\end{array}$ & Berhasil \\
\hline
\end{tabular}

2) Pengujian Intensitas Cahaya, Sudut dan Jarak antara Kamera dengan Penanda: Pengujian dilakukan di dua tempat berbeda yaitu di ruangan terbuka dan tertutup. Indikator berhasil atau tidaknya dalam pengujian ini yaitu obyek 3D beserta animasinya mucul, dan suara narasi berjalan sesuai dengan penanda yang telah dibuat. Jika objek 3D dan animasi tidak muncul dan suara narasi tidak berjalan maka pengujian 
yang dilakukan gagal. Hasil pengujian intensitas cahaya, sudut dan jarak ditunjukan pada Tabel 2 sampi dengan Tabel 3.

TABEL II PENGUJIAN PENANDA DI RUANGAN TERBUKA

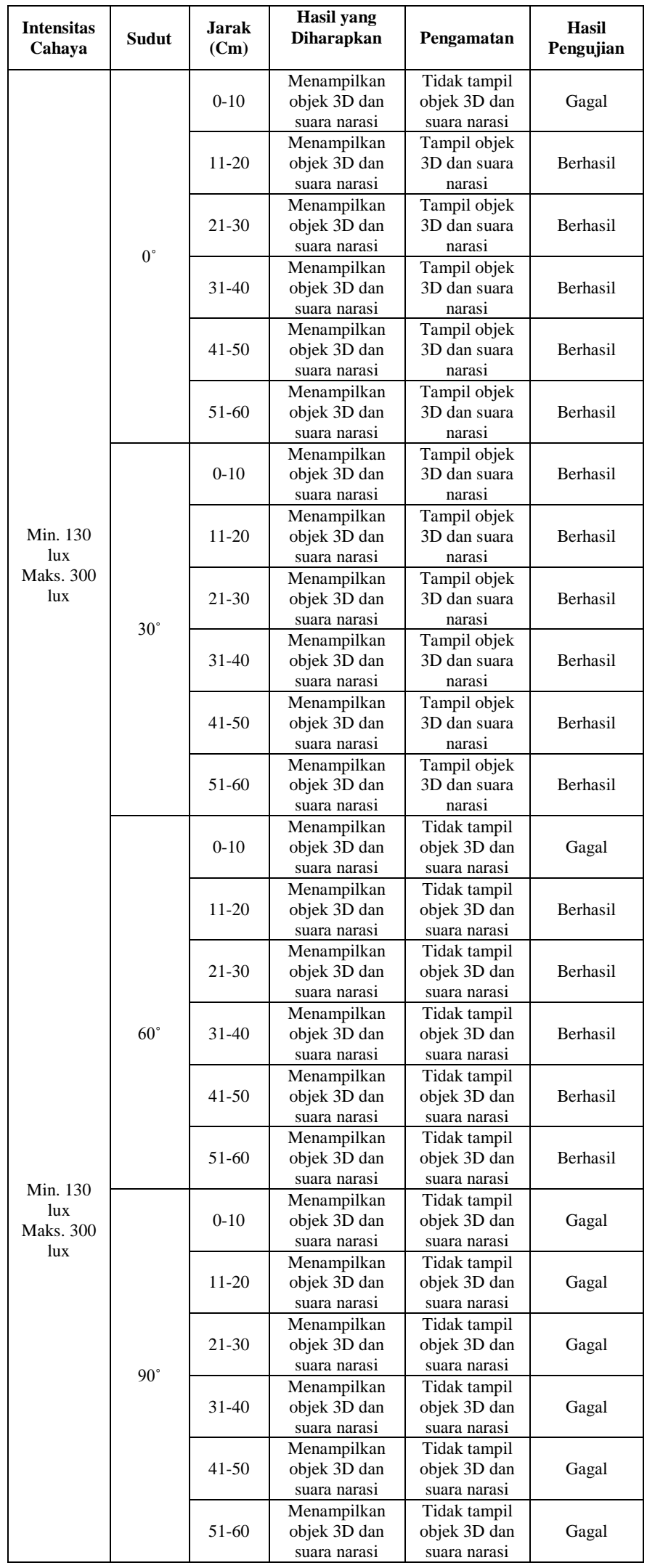

Berdasarkan Tabel 2 dapat diketahui bahwa keberhasilan mendeteksi penanda di ruang terbuka lebih baik dilakukan dengan sudut penanda $0^{\circ}, 30^{\circ}$ dan $60^{\circ}$ dibuktikan dengan mendapatkan jumlah keberhasilan yang lebih banyak di bandingkan dengan yang dilakukan pada sudut penandadan $90^{\circ}$.
TABEL III PENGUJIAN PENANDA DI RUANGAN TERTUTUP

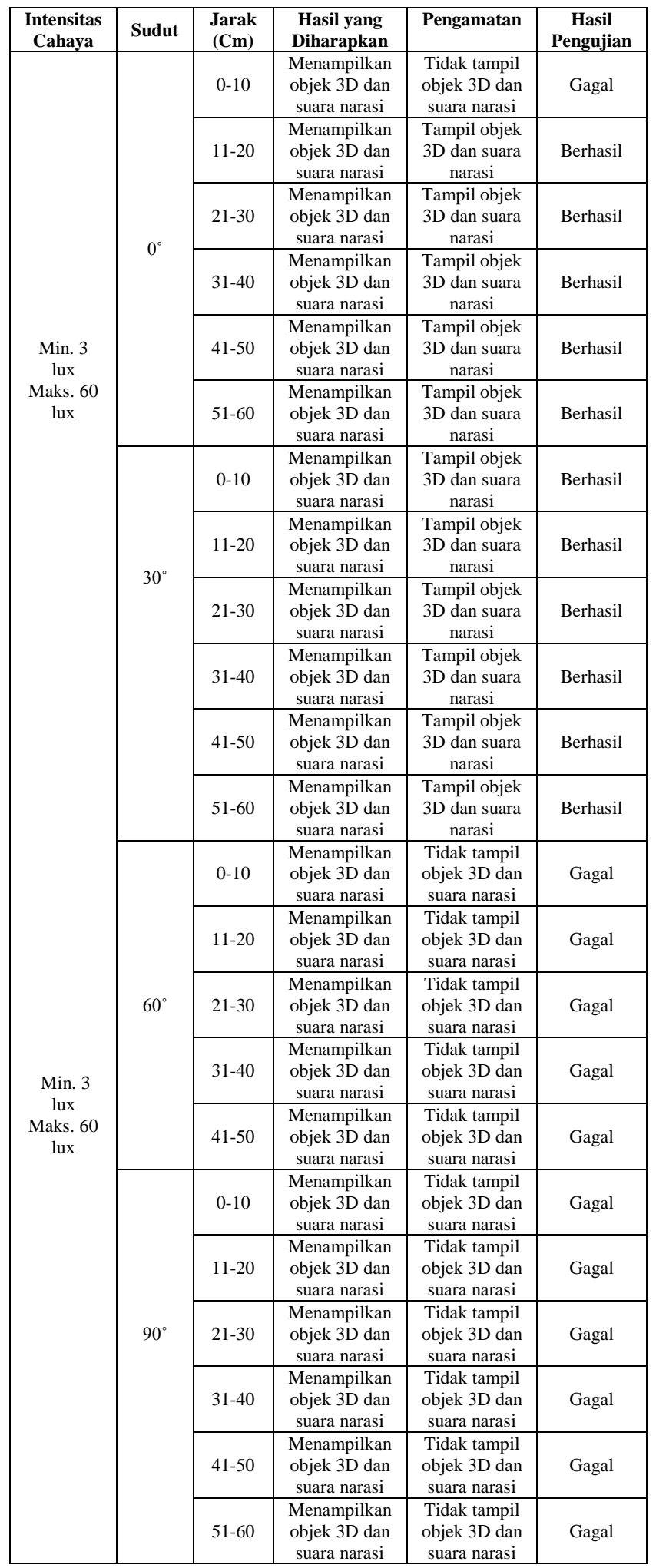

Berdasarkan Tabel 2 dan Tabel 3 diatas dapat disimpulkan bahwa intensitas cahaya dapat mempengaruhi deteksi penanda, dibuktikan dengan jumlah keberhasilan menampilkan penanda di ruang terbuka lebih banyak dibandingkan dengan keberhasilan yang dilakukan pada ruangan tertutup. Selain itu, dapat diketahui pula jarak yang baik antara penanda dengan kamera adalah lebih dari $10 \mathrm{~cm}$ hingga $60 \mathrm{~cm}$ serta sudut penanda $0^{\circ}$ dan $30^{\circ}$ merupakan sudut yang cukup baik untuk kamera mendeteksi penanda,

3) Pengujian Fungsi Tombol: Pada aplikasi ini terdapat lima pilihan menu, yaitu menu Mulai, menu Panduan, menu Tahukah Kamu?, menu Tentang Aplikasi dan menu Keluar. 
Tabel 4 menunjukkan hasil dari pengujian fungsi-fungsi yang terdapat pada aplikasi.

TABEL IV PENGUJIAN FUNGSI TOMBOL

\begin{tabular}{|c|c|c|c|c|}
\hline No. & $\begin{array}{c}\text { Nama } \\
\text { Pengujian }\end{array}$ & $\begin{array}{c}\text { Bentuk } \\
\text { Pengujian }\end{array}$ & $\begin{array}{c}\text { Hasil yang } \\
\text { Diharapkan } \\
\end{array}$ & Hasil \\
\hline 1 & $\begin{array}{l}\text { Membuka } \\
\text { aplikasi }\end{array}$ & $\begin{array}{c}\text { Menekan shortcut } \\
\text { aplikasi }\end{array}$ & $\begin{array}{c}\text { Sistem menampilkan } \\
\text { halaman awal } \\
\text { aplikasi }\end{array}$ & Berhasil \\
\hline 2 & $\begin{array}{l}\text { Pengujian } \\
\text { halaman } \\
\text { Panduan }\end{array}$ & $\begin{array}{l}\text { Menekan tombol } \\
\text { menu Panduan }\end{array}$ & $\begin{array}{l}\text { Sistem menampilkan } \\
\text { halaman Panduan }\end{array}$ & Berhasil \\
\hline 3 & $\begin{array}{c}\text { Pengujian } \\
\text { halaman } \\
\text { Tahukah } \\
\text { Kamu? }\end{array}$ & $\begin{array}{l}\text { Menekan tombol } \\
\text { menu Tahukah } \\
\text { Kamu? }\end{array}$ & $\begin{array}{c}\text { Sistem menampilkan } \\
\text { halaman Tahukah } \\
\text { Kamu? }\end{array}$ & Berhasil \\
\hline 4 & $\begin{array}{l}\text { Pengujian } \\
\text { materi siklus } \\
\text { hidrologi } 1\end{array}$ & $\begin{array}{l}\text { Menekan tombol } \\
\text { Lanjut pada } \\
\text { halaman Tahukah } \\
\text { Kamu? }\end{array}$ & $\begin{array}{l}\text { Sistem menampilkan } \\
\text { halaman materi } \\
\text { siklus hidrologi } 1\end{array}$ & Berhasil \\
\hline 5 & $\begin{array}{c}\text { Pengujian } \\
\text { tombol } \\
\text { Kembali pada } \\
\text { materi siklus } \\
\text { hidrologi } 1\end{array}$ & $\begin{array}{l}\text { Menekan tombol } \\
\text { Kembali pada } \\
\text { halaman materi } \\
\text { siklus hidrologi } 1\end{array}$ & $\begin{array}{c}\text { Sistem menampilkan } \\
\text { halaman Tahukah } \\
\text { Kamu? }\end{array}$ & Berhasil \\
\hline 6 & $\begin{array}{c}\text { Pengujian } \\
\text { tombol Menu } \\
\text { pada materi } \\
\text { siklus } \\
\text { hidrologi } 1\end{array}$ & $\begin{array}{l}\text { Menekan tombol } \\
\text { Menu pada } \\
\text { halaman materi } \\
\text { siklus hidrologi } 1\end{array}$ & $\begin{array}{c}\text { Sistem menampilkan } \\
\text { halaman menu utama } \\
\text { aplikasi }\end{array}$ & Berhasil \\
\hline 7 & $\begin{array}{l}\text { Pengujian } \\
\text { materi siklus } \\
\text { hidrologi } 2\end{array}$ & $\begin{array}{c}\text { Menekan tombol } \\
\text { Lanjut pada } \\
\text { halaman materi } \\
\text { siklus hidrologi } 1\end{array}$ & $\begin{array}{l}\text { Sistem menampilkan } \\
\text { halaman materi } \\
\text { siklus hidrologi } 2\end{array}$ & Berhasil \\
\hline 8 & $\begin{array}{c}\text { Pengujian } \\
\text { tombol } \\
\text { Kembali pada } \\
\text { materi siklus } \\
\text { hidrologi } 2\end{array}$ & $\begin{array}{l}\text { Menekan tombol } \\
\text { Kembali pada } \\
\text { halaman materi } \\
\text { siklus hidrologi } 2\end{array}$ & $\begin{array}{l}\text { Sistem menampilkan } \\
\text { halaman materi } \\
\text { siklus hidrologi } 1\end{array}$ & Berhasil \\
\hline 9 & $\begin{array}{c}\text { Pengujian } \\
\text { tombol Menu } \\
\text { pada materi } \\
\text { siklus } \\
\text { hidrologi } 2\end{array}$ & $\begin{array}{l}\text { Menekan tombol } \\
\text { Menu pada } \\
\text { halaman materi } \\
\text { siklus hidrologi } 2\end{array}$ & $\begin{array}{c}\text { Sistem menampilkan } \\
\text { halaman menu utama } \\
\text { aplikasi }\end{array}$ & Berhasil \\
\hline 10 & $\begin{array}{l}\text { Pengujian } \\
\text { materi siklus } \\
\text { hidrologi } 3\end{array}$ & $\begin{array}{c}\text { Menekan tombol } \\
\text { Lanjut pada } \\
\text { halaman materi } \\
\text { siklus hidrologi } 2\end{array}$ & $\begin{array}{l}\text { Sistem menampilkan } \\
\text { halaman materi } \\
\text { siklus hidrologi } 3\end{array}$ & Berhasil \\
\hline 11 & $\begin{array}{c}\text { Pengujian } \\
\text { tombol } \\
\text { Kembali pada } \\
\text { materi siklus } \\
\text { hidrologi } 3 \\
\end{array}$ & $\begin{array}{l}\text { Menekan tombol } \\
\text { Kembali pada } \\
\text { halaman materi } \\
\text { siklus hidrologi } 3\end{array}$ & $\begin{array}{l}\text { Sistem menampilkan } \\
\text { halaman materi } \\
\text { siklus hidrologi } 2\end{array}$ & Berhasil \\
\hline 12 & $\begin{array}{c}\text { Pengujian } \\
\text { tombol Menu } \\
\text { pada materi } \\
\text { siklus } \\
\text { hidrologi } 3 \\
\end{array}$ & $\begin{array}{l}\text { Menekan tombol } \\
\text { Menu pada } \\
\text { halaman materi } \\
\text { siklus hidrologi } 3\end{array}$ & $\begin{array}{c}\text { Sistem menampilkan } \\
\text { halaman menu utama } \\
\text { aplikasi }\end{array}$ & Berhasil \\
\hline 13 & $\begin{array}{c}\text { Pengujian } \\
\text { fungsi kamera }\end{array}$ & $\begin{array}{c}\text { Menekan tombol } \\
\text { menu Mulai pada } \\
\text { halaman menu } \\
\text { utama }\end{array}$ & $\begin{array}{c}\text { Sistem mengaktifkan } \\
\text { kamera }\end{array}$ & Berhasil \\
\hline 15 & $\begin{array}{c}\text { Pengujian } \\
\text { tombol Keluar } \\
\text { pada menu } \\
\text { utama }\end{array}$ & $\begin{array}{l}\text { Menekan tombol } \\
\text { Keluar pada } \\
\text { menu utama }\end{array}$ & $\begin{array}{c}\text { Menampilkan } \\
\text { halaman konfirmasi } \\
\text { keluar }\end{array}$ & Berhasil \\
\hline 16 & $\begin{array}{l}\text { Pengujian } \\
\text { tombol Ya }\end{array}$ & $\begin{array}{l}\text { Menekan tombol } \\
\text { Ya pada halaman } \\
\text { konfirmasi keluar }\end{array}$ & Keluar Aplikasi & Berhasil \\
\hline 17 & $\begin{array}{l}\text { Pengujian } \\
\text { tombol Tidak }\end{array}$ & $\begin{array}{l}\text { Menekan tombol } \\
\text { Tidak pada } \\
\text { halaman } \\
\text { konfirmasi keluar }\end{array}$ & $\begin{array}{c}\text { Menampilkan } \\
\text { halaman menu utama }\end{array}$ & Berhasil \\
\hline
\end{tabular}

Berdasarkan hasil pengujian yang ditunjukan pada Tabel 4 dapat simpulkan bahwa fungsionalitas tombaol aplikasi telah berjalan dengan baik sesuai dengan apa yang diharapkan, dibuktikan dengan tidak ditemukan kegagalan dalam pengujian.

\section{PENUTUP}

\section{A. Kesimpulan}

Berdasarkan hasil pengujian dan analisis pada aplikasi augmented reality siklus hidrologi, maka dapat diambil kesimpulan sebagai berikut.
1. Intensitas cahaya mempengaruhi proses pembacaan penanda oleh kamera, sehingga objek dan informasi yang telah dirancang pun mempengaruhi tampil atau tidaknya pada layar perangkat bergerak. Proses pembacaan penanda pada kondisi ruangan terbuka dengan nilai intensitas minimal 130 lux dan maksimal 300 lux akan lebih mudah dan cepat dibandingkan proses pembacaan penanda pada kondisi ruangan tertutup dengan nilai intensitas minimal 3 lux dan maksimal 60 lux.

2. Pada ruangan tertutup dengan intensitas cahaya minimal 3 lux dan maksimal 60 lux, gambar penanda dengan paduan warna yang kurang kontras yaitu gambar penanda infiltrasi tidak dapat menampilkan objek pada perangkat bergerak.

3. Jarak yang baik untuk sistem mengidentifikasi penanda yaitu lebih dari $10 \mathrm{~cm}$. Dikarenakan pada jarak 0-10 kamera perangkat hanya bisa menangkap sedikit bagian dari penanda.

4. Berdasarkan hasil uji Kotak Hitam (Black Box Testing), dapat ditunjukkan bahwa semua fungsi menu maupun tombol yang terdapat pada aplikasi telah berhasil sesuai dengan fungsinya.

\section{B. Saran}

Aplikasi media pembelajaran siklus hidrologi menggunakan teknologi augmented reality ini masih terdapat beberapa hal yang memungkinkan untuk dikembangkan selanjutnya. Beberapa saran untuk pengembangan yang lebih baik adalah sebagai berikut.

1. Perlu ditambahkan permainan sederhana misalnya kuis dari materi siklus hidrologi menggunakan Unity.

2. Perlu diberikan Flash Camera pada sistem agar membantu pendeteksian penanda pada saat berada di ruangan gelap.

3. Perlu dilakukan penelitian lanjutan terhadap sistem misalnya mengembangkan pendeteksian melalui gerakan tangan untuk mengontrol objek 3D sehingga interaksi yang diberikan lebih menarik.

4. Animasi 3D pemodelan siklus hidrologi perlu dibuat menggunakan perangkat lunak yang bervariasi agar pemodelan yang muncul semakin menyerupai aslinya, misalnya dengan Cinema 4D ataupun Autodesk 3Ds Max.

\section{DAFTAR PUSTAKA}

[1] ----, Blender (perangkat lunak). http://id.wikipedia.org/wiki/Blender_(perangkat_lunak)/, 20 April 2015.

[2] Binanto, I., Multimedia Digital Dasar Teori dan Pengembangannya, ANDI, Yogyakarta, 2010.

[3] Friedrich, W., and D. Jahn, ARVIKA Augmented Reality For Development, Production And Service, 2002.

[4] Habibie, Unity3D: Cross-Platform Game Engine. http://bloghabibie.blogspot.com/2012/04/unity3d-cross-platform-gameengine.html. 6 Maret 2015.

[5] Kusuma, D.A., Penerapan Model Pembelajaran Picture And Picture untuk Meningkatkan Hasil Belajar Siswa pada Pelajaran Teknologi Informasi dan Komunikasi di SMP, S1 thesis, Universitas Pendidikan Indonesia, Bandung, 2013.

[6] Safaat, H.N., Pemrograman Aplikasi Mobile Smartphone dan Tablet PC berbasis Android, Informatika, Bandung, 2012.

[7] Ronald T. Azuma,"A Survey of Augmented Reality, Teleoperators and Virtual Environments 6", 355-385, 1997.

[8] Soemarto, C.D., HidrologiTeknik. Usaha Nasional, Surabaya, 1987.

[9] Sosrodarsono, Suyono dan Takeda, K., Hidrologi untuk Pengairan. PT. Pradnya Paramitra, Jakarta, 1983.

[10] Suyanto, Analisis dan Desain Aplikasi Multimedia untuk Pemasaran, Yogyakarta, Andi, 2004.

[11] Syahrin, YA.,Perancangan dan Pengembangan Permainan "Super Sigi"Menggunakan Stencyl sebagai Media Pengenalan Menyikat Gigi,Skripsi S-1,Universitas Diponegoro, Semarang, 2014.

[12] Yusniawati, I., Peningkatan Hasil Belajar IPA Materi TataSurya dengan Menggunakan Media Interaktif Animasi 3 Dimensi pada Siswa Kelas VI SD Negeri 02 Tlobo KecamatanJatiyoso Kabupaten Karanganyar, Skripsi S-1,Universitas Muhammadiyah Surakarta, Surakarta, 2011. 